Original Research Paper

\title{
Assessment of the Combining Ability of Sweet Clover Basic Material in Northern Kazakhstan
}

\author{
${ }^{1}$ Gulzhiyan Begalievna Bekimova, ${ }^{1}$ Ualikhan Molgazhdarovich Sagalbekov, \\ ${ }^{1}$ Marden Ersainovich Baidalin, ${ }^{2}$ Christina Georgieva Yancheva and ${ }^{1}$ Mariya Asylkhanovna Auzhanova
}

${ }^{I}$ Sh. Ualikhanov Kokshetau State University, Kokshetau, Kazakhstan

${ }^{2}$ Agricultural University, Plovdiv, Bulgaria

Article history

Received: $13-11-2020$

Revised: 08-02-2021

Accepted: 11-02-2021

Corresponding Author:

Marden Ersainovich Baidalin,

Sh. Ualikhanov Kokshetau

State University, Kokshetau,

Kazakhstan

Email: marden_0887@mail.ru

\begin{abstract}
The paper presents the evaluation of the total combining ability of the seed parents of white sweet clover Melilotus albus and yellow sweet clover Melilotus officinalis based on leaf formation, forage productivity and seed productivity. The results of competitive heterosis for the yield of herbage, dry matter and seeds of the polycross offspring $\mathrm{Syn}_{1}$ are also presented. Among the polycross offspring Syn ${ }_{1}$ Melilotus albus, SGP-4-12507 and SGP-5-12508 were selected based on their leaf formation (50 and $50 \%$, respectively); competitive heterosis was 16.3 and $22 \%$, respectively. Based on the total combining ability of offspring $\operatorname{Syn}_{1}$ of Melilotus albus, the following biotypes were selected: SGP-2-12519 (27.1\%) and SGP-1-12503 (20.8\%) for forage productivity; SGP-4-12601 $(14.7 \%)$ and SGP-5-12508 (13.0\%) for dry matter productivity; SGP-4-12601 (50.4\%), SGP-2-12519 (19.2\%) and SGP-5-12508 (14.1\%) for seed productivity. The highest total combining ability were found for the following biotypes of Melilotus officinalis: SGP-9-12454 and SGP-10-12455 for leaf formation (18.2 and 13.3\%, respectively); SGP-10-12455 (12.5\%) for herbage productivity; SGP-10-12455 (29.6\%) and SGP-9-12454 (24.2\%) for dry matter productivity; SGP-6-12520 (15.4\%) and SGP-9-12454 (14.1\%) for seed productivity. Selected sweet clover samples can be recommended as the best basic material for further work on selection for high forage and seed productivity.
\end{abstract}

Keywords: Complex Hybrid Population, Polycross, General Combining Ability, Leaf Formation, Forage Productivity

\section{Introduction}

Relevance. Today, one of the global problems of mankind is food shortage. According to Food and Agriculture Organization (FAO) statistics, 0.8 to 1.2 billion people are malnourished and starving (FAO, 2020). Growth of the total world population by an average of 2.5 billion (30-34\%) is expected by 2050 and it will reach 9.1 billion. In this regard, the global goal is to increase production and provide humanity with high-quality environmentally safe products (Makkar et al., 2014).

The development strategy for a cost-effective highquality food sector is based on a combination of two fundamental factors: High productivity of animal products through the use of high-protein feed and low cost of forage herbs (Baidalin et al., 2017).

In the Republic of Kazakhstan, the scientifically based technical level of livestock breeding development largely determines the strategic food safety of the state due to the feed production industry, i.e., consumption of high-quality environmentally safe livestock products per capita. Therefore, it is necessary to properly improve the efficiency of livestock industry development. Climatic conditions in Kazakhstan are comfortable, there are pasture fields, natural and sown hay-meadows and farm fields that are used for feed production.

According to the Statistics Committee of Kazakhstan, forage crops acreage amounted to 3.3 million ha in 2019 (SCMNERK, 2019).

One of the challenges in the livestock industry in Kazakhstan is the lack of digestible protein in the feed of livestock animals. The content of high-quality hay, silage and haylage in the structure of produced animal feed is insufficient. All these shortcomings in feed production lead to significant feed overconsumption, low 
profitability of the livestock industry and reduce the competitiveness of livestock products in the domestic and export markets (RFCA Ratings, 2011).

Compared to other leguminous forage crops, sweet clover is a forage grass adapted to extreme environmental conditions, such as drought (Dashkevich et al., 2018), cold weather and salinization of the soil (Dzyubenko et al., 2018).

Sweet clover is an irreplaceable forage culture, rich with protein, carotene, essential amino acids and mineral salts. Sweet clover is used as a fallow crop. Sweet clover, as a salt-resistant crop, can be used as a phytomeliorant and green manure in low-output and salty soils (Zabala et al., 2018). In addition, sweet clover, as an improver of soil structure, fixes atmospheric nitrogen and accumulates biological nitrogen in the soil (Wu et al., 2016; Zhailybay et al., 2018).

Given the variety of advantages of sweet clover, it is advisable to use it as a universal forage crop to obtain inexpensive plant protein. The introduction of sweet clover in crop rotation is cost-effective and allows one to improve soil structure and increase the yield of subsequent rotation crops (Sagalbekov and Sagalbekov, 2012b).

Despite the universality of sweet clover crop, both in feed production and agriculture, studies on the selection of adapted varieties for specific soils and climate zones in Kazakhstan and other countries are scarce.

Heterosis is of paramount importance in the creation of a new synthetic clover variety. This effect largely depends on the correct selection of basic material with a high TCA to inherit economically valuable genetic traits of seed parents (Luo et al., 2016).

The value of the sweet clover fodder mass is mainly determined by the proportion of leaves, which contain the most of main nutrients, in the total mass of the plant. The higher this indicator $(\%)$, the higher the nutritional value of raw herbage and dry matter (hay) of sweet clover.

Abroad, the initial source material for obtaining new varieties and lines were such low-coumarin and highly productive varieties as Norgold (Canada), Cumino, Polara, Denta, Gülzev, Acumar and others (USA).

In China, the sweet clover selection at Lanzhou University is aimed at creating new varieties that must be adapted to the vast pastureland conditions of the country's mild climate (Luo et al., 2016).

In Russia, the sweet clover selection began in 1930 and currently, varieties such as Obskii gigant, Lyutsernovidnyi 6, Omskii skorospelyi, Om, Medet, Om 2, Sibirskii, Sibirskii 2, Vetvistyi 4I, Nemyuganskii, Severnyi and others have been cultivated and introduced into production.

In Kazakhstan, the sweet clover selection and selection of other forage grasses is conducted at Baraev Kazakh Research Institute of Grain Farming, Karabalyk Agricultural Experimental Station, Kazakh Research Institute of Feed Production, North Kazakhstan Research Institute of Agriculture and Aktobe Agricultural Feed and Pasture Experimental Station.
The state register of selection achievements in the Republic of Kazakhstan recommends the use of four varieties (Medet, 1972; Sretenskii, 1973; Akbas, 1990; 2005) of Melilotus albus, six varieties (Alsheevskii, 1968; Omskii skorospelyi, 1991; Kokpektinskii, 1993; Sarbas, 1994; Altynbas, 2015; Saragul 80, 2018) of Melilotus officinalis, Saraichik variety (2005) of Melilotus dentatus and Bars variety (2011) of Melilotus wolgicus (Adilet ILS, 2020). The varieties of Melilotus albus and Melilotus officinalis recommended for use are old-aged and in selection, these varieties are only slightly superior to wild-growing forms in morphological characteristics and the quality of feed productivity. Therefore, these varieties have several limitations: Rough beanstalks, poor tilling capacity and leaf formation, vulnerability to diseases and pests, significant coumarin content (Sagalbekov and Sagalbekov, 2012a). Therefore, it is necessary to create a highly productive sweet clover variety with high forage mass productivity, stable seed productivity and integrated resistance to adverse environmental factors for the conditions in Kazakhstan.

An analysis of the methods for breeding varieties of these species that are included in the State Register of the Republic of Kazakhstan for cultivation in the steppe and forest-steppe zones of Northern Kazakhstan showed that these varieties of Melilotus albus and Melilotus officinalis were bred using traditional selection methods: Mass selection, individual-family selection and hybridization. Therefore, new methods for creation of sweet clover varieties are needed to increase the efficiency of breeding studies.

In this regard, sweet clover breeding with the use of the polycross method has been launched in the North Kazakhstan Research Institute of Agriculture. The evolutionary method is mainly used when selection is carried out for traits controlled by natural selection (productivity, resistance to difficult environments, resistance to diseases and pests).

The scientific novelty and importance. To accelerate the production of synthetic varieties of sweet clover, the parameters of leaf formation, forage and seed productivity were evaluated in the hill-plain zone of Northern Kazakhstan using the polycross method based on the combining ability.

The research aimed to study the basic material of Melilotus albus and Melilotus officinalis based on the Total Combining Ability (TCA) of the seed parents and polycross offspring $\left(\mathrm{Syn}_{1}\right)$ and to identify best seed parents for use in breeding of a new variety.

Research objectives were:

- Study of the combining ability of seed parents of biotypes of different sweet clover varieties (Melilotus albus and Melilotus officinalis) based on leaf formation 
- Assessment of the adaptive potential of seed parent biotypes of different sweet clover varieties (Melilotus albus and Melilotus officinalis) based on forage and seed productivity

- Selection of forms that steadily retain herbage, dry matter and seed productivity in succeeding generations

\section{Materials and Methods}

The experimental work on the study of sweet clover selection material was conducted in a threeyear period sowing in 2017, 2018 and 2019 on the experimental field of North-Kazakhstan Scientific Research Institute of Agriculture LLP in 2017-2019 (Chaglinka village, Zerendinsky District, Akmola Region, Kazakhstan). Soil and climatic conditions in the years of the experiments were different. Typical for the climate of the northern region, droughts were more often observed in summer, i.e., vegetative period of sweet clover's vegetative and generative organs formation. The temperature conditions during the research varied depending on the year. The effective heat sum for the crop season (April-August) was $\sum t^{0}=$ $2,036^{\circ} \mathrm{C}$ in 2017. During the same period, the temperature regime was $\sum t^{0}=1,946^{\circ} \mathrm{C}$ in 2018 and $\sum t^{0}=2,123^{\circ} \mathrm{C}$ in 2019. Our research showed significant dependence of the yield parameters on the accumulated positive temperatures and the $\mathrm{HC}$.

Weather and climatic conditions over the years of research varied depending on the year. The humidity factor, or Hydrothermic Coefficient (HC), was calculated using the method of G.T. Selyaninov (Zinkovsky and Zinkovskaya, 2018).

Correctly selected seed parents are used as the basic material to create complex hybrid synthetic populations. In the future, they are used to breed polycross populations (heterosis). Ten promising biotypes were studied, which, according to all studied characteristics, i.e., the yield of hay and seeds, foliage and resistance to unfavorable soil and climatic conditions, showed the best results. They were included in the further selection in the nursery-garden for Complex Hybrid Populations (CHP).

Promising sweet clover varieties, corresponding to the model of the future variety and cultivated in Northern Kazakhstan with high forage and seed productivity, were selected as seed parents (biomechanical mixture) for the cultivation of CHP of Melilotus albus and Melilotus officinalis (Table 1).

The soils of the experimental field were ordinary medium-thick chernozems, the depth of the humus horizon reached $25-27 \mathrm{~cm}$, humus content was 4.71, mobile phosphorus content was $7.3 \mathrm{mg} / \mathrm{kg}$ of soil (low), potassium content was $40.9 \mathrm{mg} / \mathrm{kg}$ of soil (high), nitrogen content was $14.0 \mathrm{mg} / \mathrm{kg}$ soil (high). Consequently, the availability of nitrogen and potassium in the soil was high and the availability of phosphorus was low. The mechanical composition of the soil was slightly gravelly heavy clay loam, bulk density of the plough-layer was $1.19 \mathrm{~g} / \mathrm{cm}^{3}$, bulk density of the meter-deep layer was $1.30 \mathrm{~g} / \mathrm{cm}^{3}$ on average. The humidity of permanent wilting was $13 \%$.

Table 1: Different promising varieties for the breeding of sweet clover

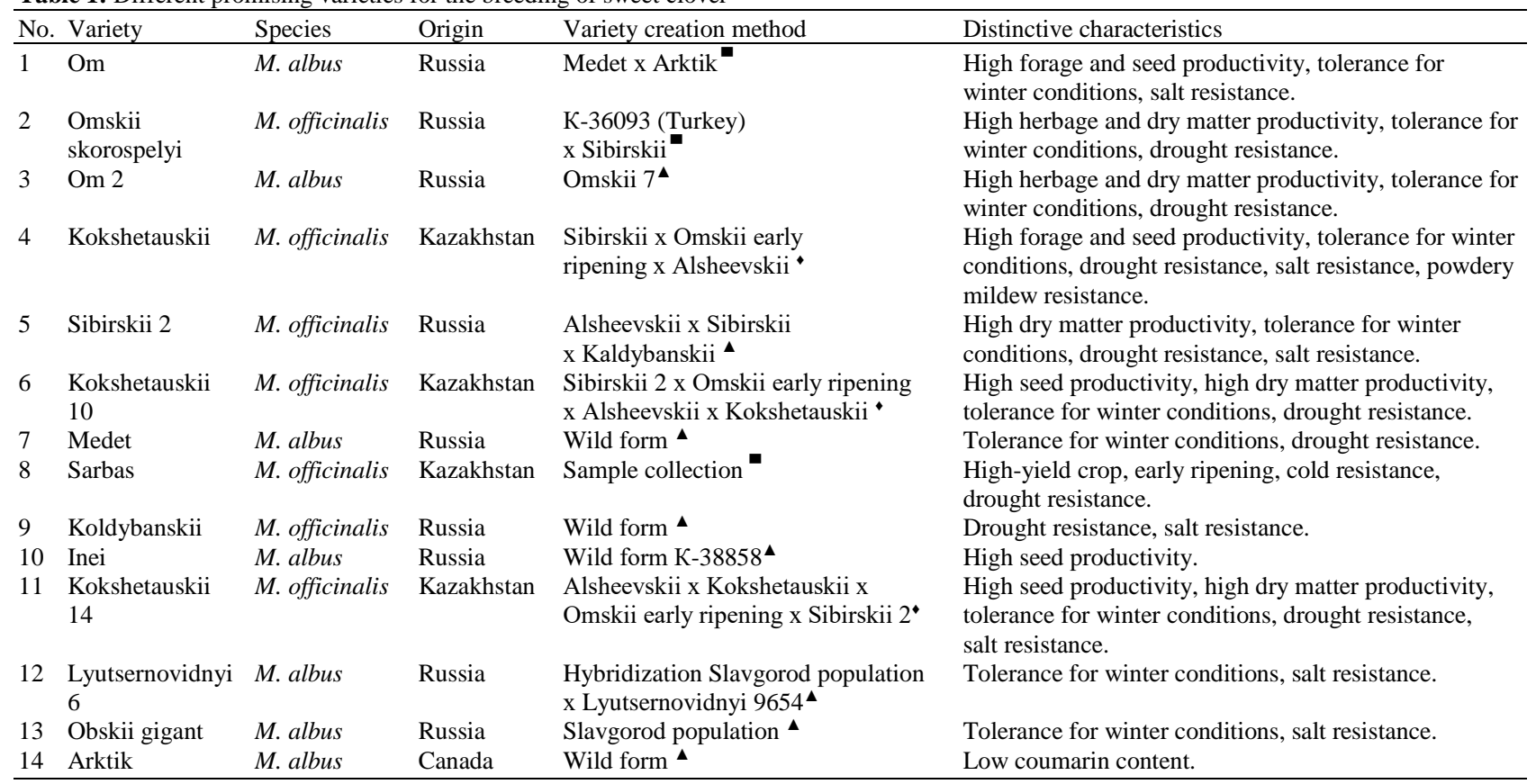


Sowing was carried out by hand in the second half of May in 2017-2019. The check-row seeding method was used with a distance of $70 \times 70 \mathrm{~cm}$ in three replications; the plot area was $25 \mathrm{~m}^{2}$. The depth of seed placement was 3 $\mathrm{cm}$. The varieties Sretenskii (for Melilotus albus biotypes) and Alsheevskii (for Melilotus officinalis biotypes) were used as a standard. The selected biotypes were mowed for herbage and the determination of dry matter content during the phase of early flowering. Hand harvest for the determination of seed productivity was performed as the beans were ripening in the second 10-day period of August, depending on the year of sowing. The sheaves were threshed on laboratory barn threshers MPTU-500 (Russia).

In our studies, TCA of sweet clover biotypes was determined using the polycross method, which allows determining the value of a large number of biotypes in breeding for heterosis, since there is a high positive correlation between the manifestation of heterosis in a certain line in single-cross hybrids with polycross (TCA) (Bekimova et al., 2020).

The polycross method consists in intervarietal cross-pollination of selected varieties and biotypes in order to create complex hybrid synthetic populations for further breeding work.

In our studies, ten biotypes of the 20 best plants of one variety were sown on separate plots on a special isolated field. As a result of their transpollination, hybrid seeds were formed (polycross synthetic hybrids).

The method of pair selection based on the combining ability of seed parents is that the breeding has an advantage: The value of varieties can be predicted based on characteristics as early as in the first generation and the selection among them can be made in subsequent generations. TCA of ten biotypes of two species of sweet clover was determined as follows: We summed up the studied parameter of hybrids of all varieties, calculated the mean for a certain polycross and calculated the deviation from mean for the studied indicator of a certain hybrid.

Also, for a comprehensive assessment of the selection material based on the important indicators of both high yield and resistance to unfavorable soil and climatic conditions, guidelines for the selection of perennial cereal grasses (Kosolapov et al., 2012) and methods for assessing combining ability in forage grasses breeding (Bozhenko et al., 2018) were used in this research. Experimental data on the yield of herbage and dry matter and seed productivity were statistically processed to identify the mean experimental error and the reliability of the scientific research using the ANOVA-SPSS.-13.5 software (Nasledov, 2011).

\section{Results and Discussion}

According to our observations, the year 2017 was dry, average $\mathrm{HC}$ was 0.8; the next (2018) year, on the contrary, was excessively wet, the HC was 2.0; the year 2019 was drier compared to 2018, the average HC was 0.7 .

The results of sweet clover mowing at the early flowering phase showed that the high feed productivity was characteristic of those biotypes, in which the proportion of leaves in the total mass of the plant was higher (Table 2).

The following $\mathrm{Syn}_{1}$ were selected among the Melilotus albus biotypes based on the leaf formation: SGP-4-12507 (50\%) and SGP-5-12508 (50\%). The competitive heterosis of these biotypes was higher - 16.3 and $22 \%$, respectively.

It should also be noted that herbage and dry matter productivity of these biotypes was higher than the productivity of other biotypes: The herbage productivity of SGP-4-12503 was 94.2 g per plant and hay productivity was $21.5 \mathrm{~g}$ per plant. In the SGP -5-12508 the herbage was 87.6 g per plant, hay - $18.4 \mathrm{~g}$ per plant (Table 3 ).

Studies of other researchers confirm our results: sweet clover varieties with high leaf formation - up to 55.7\% (Makarov and Andrusova, 2016) - have high nutritional value, tender stems and high herbage productivity (up to $1,450 \mathrm{~g} / \mathrm{m}^{2}$ ).

However, likely, the ratio of leaves and stems in the population can adversely affect the quality of the feed. A qualitative analysis of the ratio of leaves and stems in sweet clover showed that at a $50 \%$ ratio of leaves and stems the feed digestibility of $F_{1}$ was almost $60 \%$ (Zabala et al., 2018). For that reason, to create high-quality sweet clover feed, the best time for the formation of the maximum ratio of leaves and stems is the budding phase (the early flowering phase).

Table 2: The study and evaluation of polycross hybrids of Melilotus albus based on leaf formation, the average for 2017-2019

\begin{tabular}{|c|c|c|c|c|c|c|c|c|c|c|c|c|}
\hline \multirow[b]{3}{*}{ Descriptive } & \multicolumn{12}{|c|}{ Melilotus albus } \\
\hline & \multicolumn{2}{|c|}{ Sretenskii-St. } & \multicolumn{2}{|c|}{ SGP-1-12503 } & \multicolumn{2}{|c|}{ SGP-2-12519 } & \multicolumn{2}{|c|}{ SGP-3-12601 } & \multicolumn{2}{|c|}{ SGP-4-12507 } & \multicolumn{2}{|c|}{ SGP-5-12508 } \\
\hline & Syn $_{1}$ & 우 & Syn $_{1}$ & 우 & $\operatorname{Syn}_{1}$ & 운 & $\mathrm{Syn}_{1}$ & 우 & $\operatorname{Syn}_{1}$ & $q$ & $\operatorname{Syn}_{1}$ & $q$ \\
\hline Mean & 44.00 & 43.00 & 48.00 & 48.00 & 44.00 & 45.00 & 47.00 & 42.00 & 50.00 & 43.00 & 50.00 & 41.00 \\
\hline Std. Deviation & 3.48 & 3.16 & 3.57 & 7.55 & 4.69 & 5.76 & 4.27 & 9.50 & 3.57 & 3.33 & 5.95 & 3.74 \\
\hline Std. Error & 1.16 & 1.05 & 1.19 & 2.51 & 1.56 & 1.92 & 1.42 & 3.16 & 1.19 & 1.11 & 1.98 & 1.24 \\
\hline $95 \%$ Conf. Interval & 42.00 & 41.00 & 46.00 & 46.00 & 42.00 & 43.00 & 45.00 & 40.00 & 48.00 & 46.00 & 48.00 & 39.00 \\
\hline Min & 38.00 & 38.00 & 40.00 & 40.00 & 40.00 & 36.00 & 42.00 & 24.00 & 40.00 & 37.00 & 43.00 & 33.00 \\
\hline Max & 48.00 & 50.00 & 52.00 & 66.00 & 55.00 & 53.00 & 54.00 & 54.00 & 54.00 & 48.00 & 60.00 & 46.00 \\
\hline
\end{tabular}


Table 3: Evaluation of the productivity of sweet clover polycross offspring in the second year of life (average for 2017-2019)

\begin{tabular}{|c|c|c|c|c|c|c|c|c|c|c|c|c|}
\hline \multirow[b]{3}{*}{ Descriptive } & \multicolumn{12}{|c|}{ Melilotus albus } \\
\hline & \multicolumn{2}{|c|}{ Sretenskii-St. } & \multicolumn{2}{|c|}{ SGP-1-12503 } & \multicolumn{2}{|c|}{ SGP-2-12519 } & \multicolumn{2}{|c|}{ SGP-3-12601 } & \multicolumn{2}{|c|}{ SGP-4-12507 } & \multicolumn{2}{|c|}{ SGP-5-12508 } \\
\hline & Syn $_{1}$ & 우 & Syn$_{1}$ & 오 & Syn $_{1}$ & 우 & Syn $_{1}$ & 우 & Syn $_{1}$ & 우 & Syn $_{1}$ & 우 \\
\hline \multirow[t]{2}{*}{ Mean* } & 69.10 & 66.70 & 78.80 & 76.30 & 90.00 & 70.80 & 75.00 & 73.80 & 94.20 & 78.00 & 87.60 & 79.00 \\
\hline & 17.20 & 14.50 & 21.50 & 20.20 & 15.90 & 14.00 & 17.70 & 15.70 & 18.20 & 16.40 & 18.40 & 15.40 \\
\hline \multirow[t]{2}{*}{ Std. Deviation } & 2.04 & 2.92 & 5.50 & 9.40 & 13.40 & 17.00 & 4.50 & 11.50 & 13.50 & 2.23 & 5.00 & 18.90 \\
\hline & 2.48 & 4.61 & 6.10 & 5.49 & 2.40 & 1.53 & 1.99 & 2.84 & 1.90 & 2.93 & 2.78 & 2.45 \\
\hline \multirow[t]{2}{*}{ Std. Error } & 0.83 & 1.19 & 2.20 & 3.90 & 5.50 & 6.90 & 1.80 & 4.71 & 5.50 & 0.91 & 2.01 & 7.72 \\
\hline & 1.01 & 1.88 & 2.51 & 2.24 & 0.98 & 0.62 & 0.80 & 1.16 & 0.77 & 1.19 & 1.13 & 1.00 \\
\hline \multirow[t]{5}{*}{$95 \%$ Conf. Interval } & 65.60 & 63.40 & 74.90 & 72.50 & 85.50 & 67.30 & 71.30 & 70.10 & 89.50 & 74.10 & 83.20 & 75.10 \\
\hline & 16.30 & 13.80 & 20.40 & 19.20 & 15.10 & 13.30 & 17.50 & 14.90 & 17.30 & 15.60 & 16.80 & 14.60 \\
\hline & \multicolumn{12}{|c|}{ Melilotus officinalis } \\
\hline & \multicolumn{2}{|c|}{ Alsheevskii-St. } & \multicolumn{2}{|c|}{ SGP-6-12519 } & \multicolumn{2}{|c|}{ SGP-7-12510 } & \multicolumn{2}{|c|}{ SGP-8-12454 } & \multicolumn{2}{|c|}{ SGP-9-12459 } & \multicolumn{2}{|c|}{ SGP-10-12455 } \\
\hline & $\operatorname{Syn}_{1}$ & 우 & $\operatorname{Syn}_{1}$ & 오 & $\operatorname{Syn}_{1}$ & o & Syn & 우 & $\operatorname{Syn}_{1}$ & 웅 & $\operatorname{Syn}_{1}$ & 우 \\
\hline \multirow{2}{*}{ Mean* } & 69.90 & 59.50 & 79.80 & 79.80 & 90.60 & 86.40 & 94.50 & 87.80 & 98.90 & 94.50 & 105.00 & 93.30 \\
\hline & 20.10 & 15.00 & 18.60 & 15.40 & 13.90 & 13.50 & 16.10 & 20.00 & 24.80 & 21.20 & 21.00 & 16.20 \\
\hline \multirow[t]{2}{*}{ Std. Deviation } & 4.89 & 9.77 & 9.66 & 4.33 & 5.65 & 14.90 & 4.31 & 6.70 & 3.64 & 7.20 & 5.33 & 9.02 \\
\hline & 7.68 & 1.96 & 2.92 & 2.13 & 2.01 & 4.13 & 2.87 & 2.11 & 2.86 & 3.60 & 5.62 & 5.60 \\
\hline \multirow[t]{2}{*}{ Std. Error } & 1.99 & 3.99 & 3.94 & 1.77 & 2.30 & 6.09 & 1.76 & 2.73 & 1.48 & 2.94 & 2.17 & 3.68 \\
\hline & 3.13 & 0.87 & 1.19 & 0.87 & 0.82 & 1.69 & 1.17 & 0.86 & 1.17 & 1.47 & 2.29 & 2.29 \\
\hline \multirow[t]{2}{*}{$95 \%$ Conf. Interval } & 66.40 & 56.50 & 75.80 & 75.80 & 86.10 & 82.10 & 89.80 & 83.40 & 94.00 & 89.70 & 99.80 & 88.60 \\
\hline & 19.10 & 14.30 & 17.70 & 14.60 & 13.20 & 12.80 & 15.30 & 19.00 & 23.60 & 20.10 & 20.00 & 15.40 \\
\hline
\end{tabular}

Remarks: *-Total for two mowings; $* *$ in the numerator - the productivity of herbage, $* * *$ in the denominator - the yield of hay

Table 4: The study and evaluation of polycross hybrids of Melilotus officinalis based on leaf formation, the average for 2017-2019 Melilotus officinalis

\begin{tabular}{|c|c|c|c|c|c|c|c|c|c|c|c|c|}
\hline \multirow[b]{2}{*}{ Descriptive } & \multicolumn{2}{|c|}{ Alsheevskii-St. } & \multicolumn{2}{|c|}{ SGP-6-12520 } & \multicolumn{2}{|c|}{ SGP-7-12510 } & \multicolumn{2}{|c|}{ SGP-8-12454 } & \multicolumn{2}{|c|}{ SGP-9-12459 } & \multicolumn{2}{|c|}{ SGP-10-12455 } \\
\hline & Syn $_{1}$ & q & $\mathrm{Syn}_{1}$ & 오 & Syn $_{1}$ & q & Syn $_{1}$ & 오 & Syn $_{1}$ & 오 & Syn $_{1}$ & q \\
\hline Mean & 41.00 & 44.00 & 49.00 & 46.00 & 49.00 & 45.00 & 49.00 & 44.00 & 52.00 & 44.00 & 51.00 & 45.00 \\
\hline Std. Deviation & 7.20 & 2.50 & 5.67 & 4.80 & 4.55 & 3.16 & 5.23 & 4.60 & 2.57 & 2.29 & 2.95 & 2.86 \\
\hline Std. Error & 2.40 & 0.83 & 1.89 & 1.60 & 1.51 & 1.05 & 1.74 & 1.53 & 0.86 & 0.76 & 0.98 & 0.95 \\
\hline 95\% Conf. Int & 39.00 & 42.00 & 47.00 & 44.00 & 47.00 & 43.00 & 47.00 & 42.00 & 49.00 & 42.00 & 48.00 & 43.00 \\
\hline
\end{tabular}

Long-term studies also proved that genotypes with longer primary branches and lower branching stems can form high dry matter yield (Espinoza et al., 2012).

Melilotus officinalis biotypes also showed good heterosis results; a high percentage of leaf formation was noted in biotypes SGP-9-12459 (52\%) and SGP-10-12455 (51\%). Competitive heterosis was also calculated with regard to seed parents of each $\mathrm{Syn}_{1}$ and the highest heterosis was observed in the biotypes SGP-9-12459 (18.2\%) and SGP-10-12455 (13.3\%) (Table 4).

Sweet clover as green forage is mowed during the phase of budding-early flowering. This is due to the fact that during the flowering phase, the stems of the plants become coarse, lignified and unproductive - this is one of the shortcomings of the morphological structure and biology of flowering clover. However, the correct choice of period of mowing for herbage or hay makes it possible to avoid this drawback. The correct choice of mowing period allows for better ratooning and complete seed ripening, since growth does not start from the top of the apical point, but from the axillary buds on the stem (Dashkevich et al., 2018).

Herbage and hay productivity directly depends on the mowing period. If the mowing is carried out at a later date, i.e., in the flowering phase, feed productivity decreases and digestibility of feeds decreases from 71 to $63 \%$ (Zabala et al., 2018).

Another pattern in the production of sweet clover hay and haylage, in which fodder crops are cultivated on a large area, is that the moving period can be almost a month long or even longer. This ultimately leads to a decrease in the protein content in green fodder, since during the month of mowing, the sweet clover goes from the phase of budding-early flowering to the end of the flowering phase, during which the maximum fall of the main leaves occurs. In this case, the quality of the feed 
(percentage of protein in dry matter) of the studied three sweet clover varieties (Severo-Kazakhstanskii 7, Omskii skorospelyi, Kokshetauskii 10) decreased from $21.9 \%$ (budding phase) to $12.4 \%$ (end of the flowering phase) (Sagalbekov, 2013).

Therefore, it is necessary to use clover varieties of different ripeness groups. Long-term research of three sweet clover varieties (Severo-Kazakhstanskii 7, Omskii skorospelyi, Kokshetauskii 10) showed that the interstage period from aftergrowth to mowing ripeness was 63 days, 53 days and 37 days, respectively (Sagalbekov, 2013).

Consequently, it is necessary to replenish the varietal assortment of sweet clover with varieties of various ripeness groups for manufacturing application to improve feed productivity. In our studies, early-ripening and midripening biotypes were selected for the biomechanical mixture of $\mathrm{CHP}$ with regard to the zonality of the region (long winter, short summer). Therefore, assessment of the polycross offspring showed variation of herbage productivity and dry matter yield within the species. The yield of herbage and hay depending on the leaf formation also showed that the productivity of biotypes with a high ratio of leaves and stems was higher than the rest. The productivity of herbage and hay of SGP-9-12459 were 98.9 and 24.8 g per plant, respectively. The productivity of herbage and hay of SGP-10-12455 were $105 \mathrm{~g}$ per plant, $21.0 \mathrm{~g}$ per plant, respectively (Table 3 ).

The difference between Melilotus albus populations and other sweet clover species is that the former have a larger number of leaves with a higher relative leaf yield in relation to the plant itself; these signs positively affect the digestibility and palatability (Zabala et al., 2012).

The results of our studies showed that the leaf formation of the best M. albus biotypes (50\%) was 1-2\% lower than the leaf formation of selected $M$. officinalis biotypes (51-52\%), although such a small difference can be a result of the climatic conditions of a particular year or a result of inaccuracy in cultivation technology.

The herbage productivity of the best $M$. albus biotypes (90.9 g per plant) was $11 \mathrm{~g}$ per plant lower than the herbage productivity of selected biotypes of $M$. officinalis (101.9 g per plant). The hay productivity of the best M. albus biotypes (19.96 g per plant) was $2.94 \mathrm{~g}$ per plant lower than the hay productivity of the best biotypes of $M$. officinalis (22.9 g per plant).

The degree of uniformity of $M$. albus and $M$. officinalis biotypes was determined using a statistical analysis of leaf formation; the average standard deviation (std. deviation) and average error (std. error) did not exceed the permissible norm (5\%) (ANOVA).

Herbage (which was mowed at the beginning of the flowering phase, two mowings were carried out in the second year of clover vegetation), hay (dried mass of clover plants was analyzed after first and second mowings) and seeds (mowing was carried out in early September) are the basis of fodder nutritional value of sweet clover.
Several researchers proved that weather conditions have the most significant effect on the feed productivity of $M$. albus and M. officinalis and the variability of this trait is around 21-22\% (Ghaderi-Far et al., 2010).

Other researchers believe that sweet clover in areas with low feed value can produce a hay yield from 3.69 to $11 \mathrm{c} / \mathrm{ha}$, regardless of weather conditions (Makarov and Andrusova, 2016).

The conditions of the sharply continental climate of Northern Kazakhstan (during the years of research the hydrothermal index ranged from 0.7 in 2017 and 2019 to 2.0 in 2018) had a direct impact on the yield of herbage, hay and seeds of clover biotypes, but despite that, several biotypes remained stable and showed the least variability of these traits.

The variation of $M$. albus was $13.1 \%$ on average for the Sretenskii $\left(\mathrm{Syn}_{1}\right)$ standard and biotypes SGP-3-12601 (18\%), SGP-5-12508 (18.3\%) and SGP-4-12507 (23.5\%) were the best biotypes that maintained stable feed productivity regardless of weather and climate conditions. The variability of $M$. officinalis biotypes ranged from 13.8 to $41 \%$. The best biotypes of $\mathrm{Syn}_{1} M$. officinalis in terms of feed productivity were SGP-6-12519 (13.8\%), SGP-9-12459 (18.4\%) and SGP-8-12454 (19.3\%).

In Northern Kazakhstan, common sweet clover species $M$. albus and $M$. officinalis form the maximum dry matter yield of 19 known sweet clover species. This is due to the genetic disposition of $M$. albus and $M$. officinalis to drought tolerance, which was noted in studies on the content of dry matter and coumarin yield of the main species of sweet clover of European, Asian and American origin (Zhang et al., 2018).

Comparison of the dry matter productivity of $M$. albus and $M$. officinalis shows that the maximum yield was formed by $\mathrm{Syn}_{1}$ of $M$. albus - $29.9 \mathrm{~g}$ per plant (SGP-1-12503), while the dry matter yield of $\mathrm{Syn}_{1}$ of $M$. officinalis was $25.8 \mathrm{~g}$ per plant (SGP-9-12459), which is also confirmed by the phylogenetic differences between the two sweet clover species (Zhang et al., 2019).

M. officinalis showed high intraspecific variability between biotypes in terms of dry matter productivity compared to $M$. albus. This is due to the fact that $M$. officinalis plants are self-pollinated, while M. albus plants are characterized by both self-pollination and cross-pollination. This pattern of genetic diversity can also be seen in the morphoanatomical structure of seeds of sweet clover species (Zhang et al., 2019).

The combining ability manifests itself in many traits, but most often in seed productivity. Seed productivity is an important indicator for the selection of the basic material for the accelerated creation of a new variety of sweet clover and increasing of its adaptive potential. The best components selected based on this trait using the polycross method were used to create complex hybrid synthetic varieties-populations. Evaluation of the basic material based on the general combining ability, which is 
a hereditary trait and is transmitted to offspring, is the main stage in the process of creation of a synthetic variety (Sagalbekov and Sagalbekov, 2012b).

TCA of the selected basic material was assessed based on increased seed productivity to create complex biological mixtures with multiple manifestations of the heterosis effect.

The seed productivity of sweet clover largely depends on the number of days in the flowering phase. The longer the flowering phase of the plant, the higher the seed productivity (Kolyasnikova, 2013).

According to our studies, the seed productivity of $\mathrm{Syn}_{1}$ of $M$. albus biotypes ranged from 0.87 to 1.97 $\mathrm{kg} / \mathrm{ha}$, which is a good indicator, given the adverse environmental conditions (drought) during the years of research. The seed productivity of $M$. officinalis ranged from 0.68 to $2.18 \mathrm{~kg} / \mathrm{ha}$ (Table 5).

The study of the biotypes of Melilotus albus showed that there was no effect of heterosis for the $\mathrm{Syn}_{1}$ standard and the seed productivity was lower than the seed productivity of parent form by $0.1 \mathrm{~kg} / \mathrm{ha}$. At the same time, the effect of heterosis was observed for the herbage productivity of the same biotype with a difference of +2.4 $\mathrm{kg} / \mathrm{ha}$. The same pattern was found for $\mathrm{Syn}_{1}$ standard of Melilotus officinalis - a decrease in seed productivity by $0.22 \mathrm{~kg} / \mathrm{ha}$. This can be explained by the fact that varieties selected as standard have been used for many years in feed production, thereby gradually worsening their seed qualities. Consequently, the study of the combining ability to identify competitive heterosis once again proves the necessity of this task when choosing breeding material for the creation of a new synthetic variety in Kazakhstan.
TCA allows not only to assess the adaptive potential of each breeding number or variety, but also to select forms that persistently preserve the manifestation of productivity parameters in subsequent generations (Makarov and Andrusova, 2016).

An excess of productivity was noted over the years of research on economically valuable traits of the productivity of sweet clover biotypes in terms of TCA. For Melilotus albus biotypes, the excess was 9.4-37.7 $\mathrm{g}$ per plant for herbage, $0.8-1.8 \mathrm{~g}$ per plant for hay and $0.36-0.53 \mathrm{c} / \mathrm{ha}$ for seeds. For Melilotus officinalis biotypes, the excess was 39.8-47.1 g per plant for herbage, $0.1-4.1 \mathrm{~g}$ per plant for hay and $0.73-0.1 .3 \mathrm{c} / \mathrm{ha}$ for seeds.

For a better assessment of parental forms, TCA was evaluated using the competitive heterosis index $\mathrm{Syn}_{1}$ of feed and seed productivity (Nasledov, 2011).

TCA of Melilotus albus biotypes were higher than the TCA of Melilotus officinalis: SGP-5-12508 (22\%) and SGP-4-12507 (16.3\%) for leaf formation; SGP-2$12519(27.1 \%)$ and SGP-1-12503 (20.8\%) for herbage productivity; SGP-4-12601 (14.7\%) and SGP-5-12508 $(13.0 \%)$ for dry matter productivity; SGP-4-12601 $(50.4 \%)$, SGP-2-12519 (19.2\%) and SGP-5-12508 (14.1\%) for seed productivity (Table 6).

According to our studies, the following biotypes of Melilotus officinalis had high TCA values: SGP-9-12454 (18.2\%) and SGP-10-12455 (13.3\%) for leaf formation; SGP-10-12455 (12.5\%) for herbage productivity; SGP-10-12455 (29.6\%) and SGP-9-12454 $(24.2 \%)$ for dry matter productivity; SGP-6-12520 (15.4\%) and SGP-9-12454 (14.1\%) for seed productivity.

Table 5: Comparative characteristics of seed productivity of sweet clover hybrid offspring, $\mathrm{kg} / \mathrm{ha}$ (average for 2017-2019)

\begin{tabular}{|c|c|c|c|c|c|c|c|c|c|c|c|c|}
\hline \multirow[b]{3}{*}{ Descriptive } & \multicolumn{12}{|c|}{ Melilotus albus } \\
\hline & \multicolumn{2}{|c|}{ Sretenskii-St. } & \multicolumn{2}{|c|}{ SGP-1-12503 } & \multicolumn{2}{|c|}{ SGP-2-12519 } & \multicolumn{2}{|c|}{ SGP-3-12601 } & \multicolumn{2}{|c|}{ SGP-4-12507 } & \multicolumn{2}{|c|}{ SGP-5-12508 } \\
\hline & $\operatorname{Syn}_{1}$ & q & $\mathrm{Syn}_{1}$ & 우 & $\operatorname{Syn}_{1}$ & q & Syn $_{1}$ & q & $\operatorname{Syn}_{1}$ & 운 & $\operatorname{Syn}_{1}$ & 우 \\
\hline Mean & 0.87 & 0.97 & 1.42 & 1.26 & 1.43 & 1.20 & 1.97 & 1.31 & 1.61 & 1.40 & 1.78 & 1.56 \\
\hline Std. Deviation & 0.44 & 0.30 & 0.27 & 0.26 & 0.37 & 0.20 & 0.50 & 0.44 & 0.19 & 0.36 & 0.36 & 0.28 \\
\hline Std. Error & 0.15 & 0.10 & 0.37 & 0.09 & 0.12 & 0.07 & 0.17 & 0.15 & 0.06 & 0.12 & 0.12 & 0.09 \\
\hline $95 \%$ Conf. Interval & 0.83 & 0.92 & 1.35 & 1.20 & 1.36 & 1.14 & 1.87 & 1.24 & 1.53 & 1.33 & 1.69 & 1.48 \\
\hline Min & 0.50 & 0.60 & 1.00 & 1.00 & 0.90 & 0.90 & 1.30 & 0.70 & 1.30 & 1.00 & 1.20 & 1.20 \\
\hline Max & 1.40 & 1.40 & 1.80 & 1.60 & 2.00 & 1.50 & 2.80 & 2.00 & 1.90 & 2.00 & 2.40 & 2.00 \\
\hline
\end{tabular}

Melilotus officinalis

\begin{tabular}{|c|c|c|c|c|c|c|c|c|c|c|c|c|}
\hline \multirow[b]{3}{*}{ Mean } & \multicolumn{2}{|c|}{ Alsheevskii-St. } & \multicolumn{2}{|c|}{ SGP-6-12519 } & \multicolumn{2}{|c|}{ SGP-7-12510 } & \multicolumn{2}{|c|}{ SGP-8-12454 } & \multicolumn{2}{|c|}{ SGP-9-12459 } & \multicolumn{2}{|c|}{ SGP-10-12455 } \\
\hline & Syn $_{1}$ & 우 & Syn $_{1}$ & o & Syn $_{1}$ & 우 & Syn $_{1}$ & q & Syn $_{1}$ & 우 & Syn $_{1}$ & 우 \\
\hline & 0.68 & 0.90 & 1.80 & 1.56 & 1.63 & 1.66 & 2.18 & 1.91 & 1.77 & 1.77 & 2.01 & 1.83 \\
\hline Std. Deviation & 0.27 & 0.366 & 0.29 & 0.49 & 0.21 & 0.33 & 0.24 & 0.48 & 0.24 & 0.36 & 0.17 & 0.44 \\
\hline Std. Error & 0.09 & 0.12 & 0.09 & 0.16 & 0.07 & 0.11 & 0.08 & 0.16 & 0.08 & 0.12 & 0.06 & 0.15 \\
\hline $95 \%$ Conf. Interval & 0.65 & 0.86 & 1.71 & 1.48 & 1.55 & 1.58 & 2.07 & 1.81 & 1.68 & 1.68 & 1.91 & 1.74 \\
\hline Min & 0.60 & 0.40 & 1.30 & 1.00 & 1.40 & 1.30 & 1.80 & 1.20 & 1.40 & 1.30 & 1.80 & 1.30 \\
\hline Max & 0.90 & 1.60 & 2.20 & 2.60 & 2.00 & 2.30 & 2.60 & 2.60 & 2.10 & 2.00 & 2.30 & 2.60 \\
\hline
\end{tabular}


Table 6: Competitive heterosis of polycross offspring of Syn 1 sweet clover, \%

\begin{tabular}{|c|c|c|c|c|c|c|c|c|c|c|c|c|}
\hline \multirow{3}{*}{$\begin{array}{l}\text { Competitive } \\
\text { heterosis, \% }\end{array}$} & \multicolumn{12}{|c|}{ Melilotus albus } \\
\hline & \multicolumn{2}{|c|}{ Sretenskii - St. } & \multicolumn{2}{|c|}{ SGP-1-12503 } & \multicolumn{2}{|c|}{ SGP-2-12519 } & \multicolumn{2}{|c|}{ SGP-3-12601 } & \multicolumn{2}{|c|}{ SGP-4-12507 } & \multicolumn{2}{|c|}{ SGP-5-12508 } \\
\hline & Syn$_{1}$ & q & $\mathrm{Syn}_{1}$ & 운 & $\operatorname{Syn}_{1}$ & q & Syn $_{1}$ & 우 & Syn $_{1}$ & 우 & Syn$_{1}$ & q \\
\hline Leaf formation & 2.3 & - & 0.0 & - & -2.3 & - & 11.9 & - & 16.3 & - & 22.0 & - \\
\hline Herbage & -3.5 & - & 20.8 & - & 27.1 & - & 1.6 & - & 3.3 & - & 10.9 & - \\
\hline Dry matter & -15.7 & & -9.9 & & 11.9 & & 6.0 & & 14.7 & & 13.0 & \\
\hline \multirow[t]{4}{*}{ Seeds } & -10.3 & - & 12.7 & - & 19.2 & - & 1.5 & - & 50.4 & - & 14.1 & - \\
\hline & \multicolumn{12}{|c|}{ Melilotus officinalis } \\
\hline & \multicolumn{2}{|c|}{ Alsheevskii - St. } & \multicolumn{2}{|c|}{ SGP-6-12519 } & \multicolumn{2}{|c|}{ SGP-7-12510 } & \multicolumn{2}{|c|}{ SGP-8-12454 } & \multicolumn{2}{|c|}{ SGP-9-12459 } & \multicolumn{2}{|c|}{ SGP-10-12455 } \\
\hline & $\operatorname{Syn}_{1}$ & q & $\operatorname{Syn}_{1}$ & q & $\operatorname{Syn}_{1}$ & o & $\operatorname{Syn}_{1}$ & o & $\operatorname{Syn}_{1}$ & o & $\operatorname{Syn}_{1}$ & q \\
\hline Leaf formation & -6.8 & - & -6.8 & - & -8.2 & - & 11.4 & - & 18.2 & - & 13.3 & - \\
\hline Herbage & 17.5 & - & 0.0 & - & -4.6 & - & -7.1 & - & 4.7 & - & 12.5 & - \\
\hline Dry matter & 34.0 & & 20.8 & & -2.9 & & 17.0 & & 24.2 & & 29.6 & \\
\hline Seeds & -2.4 & - & 15.4 & - & -1.8 & - & 14.1 & - & 0.0 & - & 9.8 & - \\
\hline
\end{tabular}

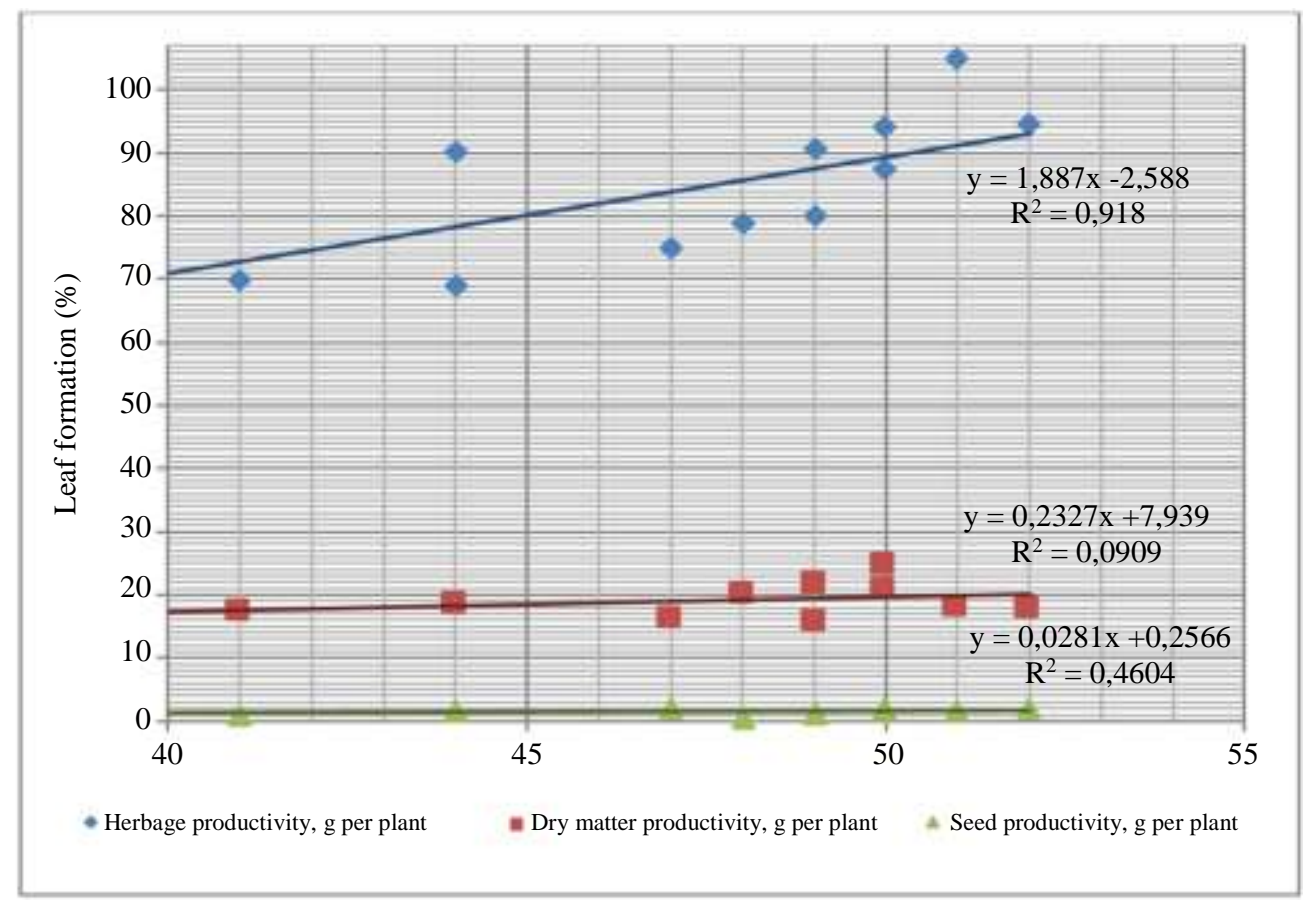

Fig. 1: Correlation coefficient between leaf formation and productivity, $r$

As several researchers observed, an inverse correlation is observed between herbage productivity and seed productivity (Zhang et al., 2019).

However, no such correlation between these traits was observed in our studies. Nevertheless, we can conclude that herbage productivity and seed productivity independently showed a positive direct correlation, since the same biotypes that showed high herbage productivity also showed high seed productivity.

Statistical analysis was conducted to determine the correlation dependence of clover biotypes for the main productivity parameters: Between leaf formation and herbage productivity, leaf formation and dry matter productivity, leaf formation and seed productivity. Figure 1 shows a close correlation between leaf formation and herbage productivity $(\mathrm{r}=0.73)$.

Dry matter productivity was an independent trait in relation to leaf formation, the correlation dependence was very weak, the coefficient was $r=0.30$. The same was true for seed productivity and leaf formation, the dependence was very weak, the correlation coefficient was $r=0.33$. 
It can be concluded that the maximum proportion of leaves in the plant is important in the initial period of the formation of herbage of sweet clover, since the obtained haylage and silage are succulent feeds and mainly consist of the herbage of clover leaves. For this reason, the mowing period for sweet clover should be during the budding phase, when the maximum formation of the vegetative mass of clover is observed (Sagalbekov and Sagalbekov, 2012a; Kolyasnikova, 2013).

\section{Conclusion}

The results of the analysis of the combining ability of seed parents of sweet clover biotypes showed a complicated inheritance of the productivity of herbage, hay and seeds.

In the studies of general combining ability of sweet clover biotypes, productivity indicators are subject to a strong modifying effect of the environment.

SGP-4-12601, SGPb5-12508, SGP-9-12454 and SGP-10-12455 can be highlighted as valuable biotypes among the studied biotypes of Melilotus albus and Melilotus officinalis; they are characterized by plasticity and stability of forage and seed productivity.

Selected sweet clover biotypes will be used in the future as selection material for breeding a new plastic and stable synthetic variety for the changing soil and climatic conditions of the sharply continental climate of Northern Kazakhstan.

\section{Acknowledgment}

The research is funded by the Committee of Science under the Ministry of Education and Science of the Republic of Kazakhstan (Grant No. AP09058089).

\section{Author's Contributions}

All authors contributed equally.

\section{Ethics}

This article is original and contains unpublished material. The corresponding author confirms that all of the other authors have read and approved the manuscript and no ethical issues involved.

\section{References}

Adilet ILS, 2020. Legal information system of Regulatory Legal Acts of the Republic of Kazakhstan. http://adilet.zan.kz/eng

Baidalin, M. E., Zhumagulov, I. I., Sagalbekov, E. U., \& Sagalbekov, U. M. (2017). Ways of Increasing Seed Germination of Sweet Clover and Methods of Reducing the Amount of Coumarin in the Leaf-Stem Mass. OnLine Journal of Biological Sciences, 17(2), 128-135.
Bekimova, G. B., Sagalbekov, U. M., \& Baidalin, M. E. (2020). Results of evaluation of complex hybrid populations of sweet clover in the nursery of competitive variety testing in the conditions of Northern Kazakhstan. 3i: intellect, idea, innovation, $1,46-51$.

Bozhenko, A. I., Sizenko, E. E., \& Kobyzskaya, L. I. (2018). Ispol'zovanie metodov otsenki kombinatsionnoi sposobnosti v selektsii kormovykh trav. Kormi i kormovirobnitstvo, 86, 11-21.

Dashkevich, S., Filippova, N., Utebayev, M., \& Abdullaev, K. (2018). Assessing the Influence of the Initial Forms of Melilot on the Quality of Fodder Mass in the Conditions of Northern Kazakhstan. Journal of Pharmaceutical Sciences and Research, 10(10), 2564-2567.

Dzyubenko, N. I., Duk, O. V., Malyshev, L. L., Prosvirin, Y. A., \& Kosareva, I. A. (2018). Screening of sweet clover (Melilotus Adans.) species diversity for resistance to chloride salinization. Sel'skokhozyaǐstvennaya Biologiya, 53(6), 1294-1302.

Espinoza, L. D. C. L., Huguet, T., \& Julier, B. (2012). Multi-population QTL detection for aerial morphogenetic traits in the model legume Medicago truncatula. Theoretical and Applied Genetics, 124(4), 739-754.

FAO. (2020). Food and Agriculture Organization. http://www.fao.org/

Ghaderi-Far, F., Gherekhloo, J., \& Alimagham, M. (2010). Influence of environmental factors on seed germination and seedling emergence of yellow sweet clover (Melilotus officinalis). Planta daninha, 28(3), 463-469.

Kolyasnikova, N. L. (2013). The flowering and seed production species of Melilotus albus and Melilotus officinalis. Middle East journal of scientific research, 16(11), 1466-1469.

Kosolapov, V. M., Kostenko, S. I., Pilipko, S. V., Klochkova, V. S., .. \& Kostenko, N. Y. (2012). Metodicheskie ukazaniya po selektsii mnogoletnikh zlakovykh trav [Methodical instructions on selection of perennial grasses]. RSAU - MTAA, Moscow. ISBN: 978-5-9675-0709-0.

Luo, K., Jahufer, M. Z. Z., Wu, F., Di, H., Zhang, D., Meng, X., ... \& Wang, Y. (2016). Genotypic variation in a breeding population of yellow sweet clover (Melilotus officinalis). Frontiers in plant science, 7, 972.

Makarov, V. P., \& Andrusova, G. M. (2016). History and prospects of Melilot breeding in Transbaikalia. Proceedings on applied botany, genetics and breeding, 177(4), 57-69.

Makkar, H. P., Tran, G., Heuzé, V., \& Ankers, P. (2014). State-of-the-art on use of insects as animal feed. Animal Feed Science and Technology, 197, 1-33. 
Nasledov, A. N. (2011). Professionalnyi statisticheskii analiz dannykh [Professional statistical data analysis]. Piter, Moscow. ISBN: 978-5-459-00344-4.

RFCA Ratings. (2011). Analiz otrasli zhivotnovodstva Respubliki Kazakhstan [Analysis of the livestock industry of the Republic of Kazakhstan]. http://www.rfcaratings. kz/ru/node/45

Sagalbekov, E. U., \& Sagalbekov, U. M. (2012a). Metodicheskie osnovy i tekhnika selektsii mnogoletnikh trav v Severnom Kazakhstane [Methodological fundamentals and techniques for breeding perennial grasses in Northern Kazakhstan]. Kokshetau.

Sagalbekov, U. M., \& Sagalbekov, E. U. (2012b). Primenenie metoda polikrossa $\mathrm{v}$ selektsii donnika [Application of the polycross method in the selection of sweet clover]. Proceedings of the International scientific and practical conference on the 100th anniversary of Siberian breeding, VariantOmsk, Omsk, pp: 258-263.

Sagalbekov, U. M. (2013). Sposob uluchsheniya kachestva korma iz donnika. Innovatsionnyi patent na izobretenie No. 27417 [Method for improvement of the quality of sweet clover feed. Innovative patent for invention No. 27417].

SCMNERK. (2019). Statisticheskie pokazateli [Statistical Indicators]. Statistics Committee of the Ministry of National Economy of the Republic of Kazakhstan.

Wu, F., Zhang, D., Ma, J., Luo, K., Di, H., Liu, Z., ... \& Wang, Y. (2016). Analysis of genetic diversity and population structure in accessions of the genus Melilotus. Industrial Crops and Products, 85, 84-92.
Zabala, J. M., Schrauf, G., Baudracco, J., Giavedoni, J., Quaino, O., \& Rush, P. (2012). Selection for late flowering and greater number of basal branches increases the leaf dry matter yield in Melilotus albus Desr. Crop and Pasture Science, 63(4), 370-376.

Zabala, J. M., Marinoni, L., Giavedoni, J. A., \& Schrauf, G. E. (2018). Breeding strategies in Melilotus albus Desr., a salt-tolerant forage legume. Euphytica, 214(2), 1-15.

Zhailybay, K. N., Medeuova, G. Z., Mirzabek, K. A., \& Nurmash, N. K. (2018). Agrobiological Foundations of the Productivity of Sweet clover. 10th International Conference on Chemical, Agricultural, Biological and Environmental Sciences (CABES18) March 19-20, 2018, Dubai (UAE). http://uruae.org/siteadmin/upload/8309AE03182008 .pdf

Zhang, H., Bai, R., Wu, F., Guo, W., Yan, Z., Yan, Q., ... \& Zhang, J. (2019). Genetic diversity, phylogenetic structure and development of core collections in Melilotus accessions from a Chinese gene bank. Scientific reports, 9(1), 1-9.

Zhang, J., Di, H., Luo, K., Jahufer, Z., Wu, F., Duan, Z., ... \& Wang, Y. (2018). Coumarin Content, Morphological Variation and Molecular Phylogenetics of Melilotus. Molecules, 23(4), 810.

Zinkovsky, V. N., \& Zinkovskaya, T. S. (2018). Considering atmospheric precipitations at agromeliorative calculations. International Research Journal, 5(71), 130-135. 